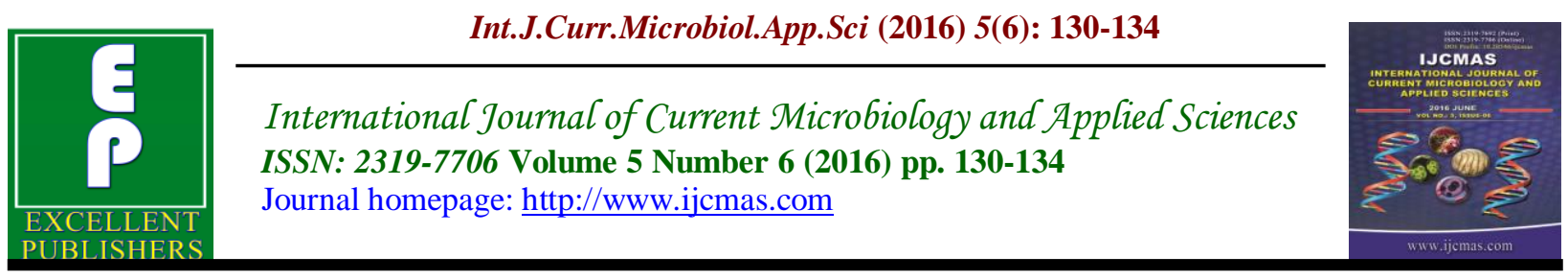

Original Research Article

http://dx.doi.org/10.20546/ijcmas.2016.506.016

\title{
Seroprevalence of Dengue in Rural Tertiary Care Hospital at Puducherry-A Retrospective Study
}

\author{
R. Balamurugan ${ }^{\text {** }}$, Sunil S. Shivekar ${ }^{2}$, R. Gopal ${ }^{2}$, M. Kaviraj ${ }^{2}$, \\ T. Mangaiyarkarasi ${ }^{2}$ and M. Saleem ${ }^{2}$ \\ ${ }^{1}$ Central Research Laboratory, Sri Manakula Vinayagar Medical College and \\ Hospital, Puducherry, India \\ ${ }^{2}$ Department of Microbiology, Sri Manakula Vinayagar Medical College and \\ Hospital, Puducherry, India \\ *Corresponding author
}

\begin{abstract}
A B S T R A C T
Keywords

Dengue, mosquito borne viral infection, IgM Microlisa, Seroprevalence, Aedes aegypti.

\section{Article Info}

Accepted:

11 May 2016

Available Online:

10 June 2016

Dengue is a mosquito borne viral infection associated with Dengue Hemorrhagic Fever (DHF) or Dengue Shock Syndrome (DSS). A changing frequency was seen on the epidemiology of dengue across India. This study is a report on the prevalence of dengue in a tertiary care hospital, Puducherry, India. This study was conducted from februry 2014 to February 2015 at Sri Manakula Vinayagar Medical College and Hospital, Puducherry. Patients with a suspected dengue infection were screened by ELISA (Dengue IgM Microlisa). The study includes 704 patients of both sexes and of all ages. From the total study population, 98 cases (13.9\%) were dengue positive, with 58 males and 40 females. Seroprevalence was high in the 3145 age group. Timely diagnosis would help for the better management of patients as if there is no specific antiviral therapy available for dengue. Controlling the vector Aedes aegypti, would be helpful to contain the spread of dengue.
\end{abstract}

\section{Introduction}

Dengue is caused by Dengue virus (DENV), a mosquito-borne flavivirus. DENV is a single stranded RNA virus of the family Flaviviridae, genus Flavivirus. DENV causes a wide range of diseases in humans, from a self limited Dengue Fever (DF) to a life-threatening syndrome called Dengue Hemorrhagic Fever (DHF) or Dengue Shock
Syndrome (DSS). There are four antigenically different serotypes of the virus: DENV-1, DENV-2, DENV-3 and DENV-4. A serotype is a group of viruses classified together based on their surface antigens. These four serotypes are different strains of dengue virus that have $60-80 \%$ homology between each other. Infection induces lifelong protection against the infecting 
serotype, but it gives only a short time cross protective immunity against the other types. The first infection most often cause a minor disease, but secondary infections have been reported to cause severe diseases (DHF or DSS) in both children and adults. In the early 1900s, spread of dengue was explosive and accompanied the movement of people across continents because of the slave trade and the two World Wars. India was one of the major country affected (Cecilia et al., 2004). Presently, about $40 \%$ of the world's population is at risk and there are 50-100 million cases every year. An estimated 500 000 people with severe dengue require hospitalization each year and about $2.5 \%$ of those affected die (WHO, 2014). In the last few years, dengue has re-emerged in the United States of America and has made inroads into Europe (Alves et al., 2013). In India, dengue is widespread and endemic in most major cities (NVBDCP. 2014).

\section{Materials and Methods}

This hospital based retrospective study was carried out at department of Microbiology, Sri Manakula Vinayagar Medical College and Hospital, a tertiary care hospital, at Puducherry. Patients admitted to the wards with clinically suspected dengue/DHF/DSS during February 2015 to February 2016 were included in this study. Patients with manifestations like headache, retro orbital pain, myalgia, arthralgia, rash, hemorrhagic manifestations, and leucopenia as described by WHO were considered as suspected case. A total no of 704 patients were screened for dengue by ELISA (Dengue IgM Microlisa). ELISA test was done as per the manufacturer's protocol. Patients irrespective of all ages from puducherry region and also from the neighboring districts were included in this study.

\section{Results and Discussion}

Out of 704 patients screened for dengue fever, 98 cases $(13.9 \%)$ were found to be positive. Among them 58 (16.8\%) were male and $40(11.2 \%)$ were female (Table 1$)$. Highest rate of infection is found in the month of November and December, however the infection rate started increasing from the month of July and declined by the month of January (Table 2). People in the age group 31 to $45(21.5 \%)$ had a higher prevalence (Table.2) when compared to other age groups.

Dengue is one of the seasonal outbreak diseases posing a global threat. Dengue infection and outbreak was already reported from various parts of the India (Table.3). It was reported earlier in Nagpur in 1965 (Rodrigues et al., 1972). In Maharashtra, the dengue outbreak was reported from Parbhani (Mehendale et al., 1991) and Dhule (Padbidri et al., 1996). Outbreak of dengue was also reported from other states of India, like Bangalore (George et al., 1975) Punjab (Kaur et al., 1997) and Delhi (Gupta et al., 2005). Our current study clearly shows that, among the total patients tested, $13.9 \%$ of the people were positive for dengue fever. Adult in the age groups of 31 to 45 years were found to be more infected than other age groups. It was also noted that number of positive cases started increasing from monsoon season to post monsoon season, because that season is considered as favorable for breeding of the vector, i.e., Aedes aegypti. 
Table.1 Age and sex distribution of patients tested for dengue serology

\begin{tabular}{|c|c|c|c|c|}
\hline \multirow{3}{*}{\begin{tabular}{ll}
\multicolumn{1}{c}{ Age } \\
$<15$ & \\
& $\mathrm{~N}=130$
\end{tabular}} & \multirow{3}{*}{$\frac{\text { Sex }}{\mathrm{M}}$} & \multirow{3}{*}{$\begin{array}{c}\text { Total } \\
67 \\
60\end{array}$} & \multicolumn{2}{|c|}{ Positive } \\
\hline & & & 9 & $13(10 \%)$ \\
\hline & & & 4 & $15(1070)$ \\
\hline \multirow[t]{2}{*}{$16<>30$} & M & 99 & 21 & \multirow{2}{*}{$33(15.5 \%)$} \\
\hline & $\mathrm{F}$ & 114 & 12 & \\
\hline \multirow{2}{*}{ 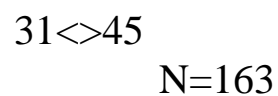 } & $\mathrm{M}$ & 74 & 17 & \multirow{2}{*}{$35(21.5 \%)$} \\
\hline & $\mathrm{F}$ & 89 & 18 & \\
\hline \multirow{2}{*}{$\begin{array}{l}46<>60 \\
N=117\end{array}$} & $\mathrm{M}$ & 59 & 8 & \multirow{2}{*}{$14(12 \%)$} \\
\hline & $\mathrm{F}$ & 58 & 6 & \\
\hline \multirow[b]{2}{*}{$\mathrm{N}=81$} & $\mathrm{M}$ & 47 & 3 & \multirow{2}{*}{$3(3.7 \%)$} \\
\hline & $\mathrm{F}$ & 34 & 0 & \\
\hline \multirow{2}{*}{$\begin{array}{l}\text { TOTAL } \\
\mathrm{N}=704\end{array}$} & $\mathrm{M}$ & 346 & $58(16.8 \%)$ & \multirow{2}{*}{$98(13.9 \%)$} \\
\hline & $\mathrm{F}$ & 358 & $40(11.2 \%)$ & \\
\hline
\end{tabular}

Table.2 Month wise distribution of cases tested for dengue seropositivity

\begin{tabular}{|c|c|c|}
\hline Month & Total & Positive \\
\hline Feb-15 & 86 & 2 \\
\hline Mar-15 & 26 & 5 \\
\hline Apr-15 & 0 & 0 \\
\hline May-15 & 4 & 1 \\
\hline Jun-15 & 3 & 0 \\
\hline Jul-15 & 66 & 8 \\
\hline Aug-15 & 33 & 7 \\
\hline Sep-15 & 72 & 8 \\
\hline Oct-15 & 41 & 11 \\
\hline Nov-15 & 91 & 16 \\
\hline Dec-15 & 147 & 25 \\
\hline Jan-16 & 109 & 14 \\
\hline Feb-16 & 26 & 1 \\
\hline Total & 704 & 98 \\
\hline
\end{tabular}


Table.3 Seroprevalence of dengue in different studies across the country

\begin{tabular}{|c|c|l|c|}
\hline Period/ Year & Region & \multicolumn{1}{|c|}{ Author/ Study } & Prevalence \\
\hline $\begin{array}{c}\text { Apr-may 1994 } \\
\text { 2003(outbreak) }\end{array}$ & Dhule & Padbidri et.al., 1996 & $15.4 \%$ \\
\hline $\begin{array}{c}\text { July 2003 } \\
\text { (outbreak) }\end{array}$ & Kanyakumari & Gupta et.al., 2005 & $58.3 \%$ \\
\hline 2010 (outbreak) & Delhi & Nishat et.al., 2010 & $38.9 \%$ \\
\hline $\begin{array}{c}\text { Sep2011-nov } \\
2012\end{array}$ & Ahemedabad & Lata R. Patel et.al., 2013 & $16.3 \%$ \\
\hline $2011-2013$ & North india & Om prakash et.al.,2015 & $22 \%$ \\
\hline $2012-2013$ & Andhra & Srinivas et.al.,2013 & $53.2 \%$ \\
\hline $2014-2015$ & Rajasthan & Kumar et.al.,2015 & $3.55 \%$ \\
\hline $2014-2015$ & Madurai & Jhansi et.al.,2015 & $20.3 \%$ \\
\hline
\end{tabular}

Many dengue cases were reported during the post monsoon season, i.e., from September to November in various studies reported in India (George et al., 1975, Kaur et al., 1997). In our study the maximum number of cases was seen in the month of December, a post monsoon period in Tamilnadu and Puducherry. This result is concordant with other studies and found to be lasting till the end of winter season. Infection rate of dengue at this tertiary care hospital is $13.9 \%$. This may be considered as quite high. Majority of the people attending the hospital were from rural areas. Poor sanitation, improper drainage system, habitats near water logging or stagnant area and near the trees where the mosquitoes breed may be the reason for this high prevalence rate.

In conclusion, dengue is a rapidly emerging viral disease increasingly reported from many countries particularly south Asian countries like India with seasonal outbreaks of epidemics with a high morbidity and mortality in some places. Control of the vector population is a key to the success of containing the disease. Early diagnosis and appropriate treatment with platelet transfusion where indicated will reduce the mortality rate. Sustained implementation of vector control measures by the government and the community and creating awareness among the people about the disease epidemiology will go a long way in achieving the goal of containing the disease and prevent the outbreaks.

\section{References}

Alves, M.J., Fernandes, P.L., Amaro, F., Osório, H., Luz, T,. Parreira, P., Andrade, G., Ze-Ze, L., Zeller, H. 2013. Clinical presentation and laboratory findings for the first autochthonous cases of dengue fever in Madeira island, Portugal. Euro Surveill., 18(6): 1-4

Cecilia, D. 2004. Dengue Re-emerging disease. In: NIV Commemorative Compendium. National Institute of Virology, Golden Jubilee Publication., 278-307.

George, S., Soman, R.S. 1975. Studies on Dengue in Bangalore City: Isolation of virus from Man and Mosquitoes. Indian J. Med. Res., 63: 396-401.

Gupta, E., Dar, L., Narang, P., Srivastava, V.K., Broor, S. 2005. Serodiagnosis of dengue during an outbreak at a tertiary 
care hospital in Delhi. Indian J. Med. Res., 121: 36-8.

Jhansi Charles, Ramesh, A., Anand Janagond, Rajendran, T,. Thilakavathy, P., Vithiya, G. 2015. Study of Prevalence of Dengue infection in a Rurally situated Tertiary Care Medical College Hospital at Madurai, Tamilnadu. IOSR- J. Dent. Med. Sci., 14(10): 32-36.

Kaur, H., Prabhakar, H., Mathew, P., Marshalla, R., Arya, M. 1997. Dengue haemorrhagic fever outbreak in October, November 1996 in Ludhiana, Panjab, India. Indian J. Med, Res., 106: 1-3.

Lata, R.P. 2013. Sero prevalence of Dengue NS-1 Antigen in Tertiary care hospital, Ahmedabad. Indian J. Basic \& Appl. Med. Res., 2(7): 694-701.

Mahesh Kumar, Rohitash Sharma, Geeta Parihar, Mukesh Sharma, 2015. Seroprevalence of Dengue in Central Rajasthan: A Study at a Tertiary Care Hospital. Int. J. Curr. Microbiol. App. Sci., 4(9): 933-40.

Mehendale, S.M., Risbud, A.R., Rao, J.A., Banerjee, K. 1991. Outbreak of Dengue fever in rural areas of Parbhani district of Maharashtra, India. Indian J. Med. Res., 93: 6-11.

Nishat, H.A., Shobha, B. 2014. Dengue Fever Outbreak in Delhi, North India: A Clinico-Epidemiological Study. Indian J. Community Med., 40(2): 135-8.

NVBDCP. 2014. Dengue/ dengue haemorrhagic fever. National Vector Borne Disease Control Programme (NVBDCP).
Om Prakash, Desh Deepak Singh, Geetika Mishra, Shantanu Prakash, Arvind Singh, Shikha Gupta, Jasmeet Singh, Danish Nasar Khan, Parul Jain, Anamika Vishal, Manoj Kumar Pandey, Amita Jain. 2015. Observation on dengue cases from a virus diagnostic laboratory of a tertiary care hospital in north India. Indian $J$. Med. Res., 142:7-11

Padbidri, V.S., Mahadev, P.V., Thakre, J.P., Pant, U., Illkal, M.A., Varghese, G.G. 1996. Virological and entomological investigations of an outbreak of Dengue fever in Dhule district, Maharashtra. Indian J. Med. Microbiol., 14:25-32.

Paramasivan, R., V. Thenmozhi, J. Hiriyan, K.J. Dhananjeyan, B.K. Tyagi, A.P. Dash. 2006. Serological \& entomological investigations of an outbreak of dengue fever in certain rural areas of Kanyakumari district, Tamil Nadu. Indian J. Med. Res., 123: 697-701.

Rodrigues, F.M., Patankar, M.R., Banerjee, K., Bhatt, P.N., Goverdhan, M.K., Pavri, K.M., M. Vittal. 1972. Etiology of the 1965 epidemic of febrile illness in Nagpur City, Maharashtra state, India. Bull. WHO., 46: 173-9.

Srinivas Rao, M.S., Pavani, K., Manick, Dass, Kareem, M.A., Vinayaraj, E.V. 2013. Seroprevalence of dengue virus in a tertiary care hospital, Andhra Pradesh, South India. Int. J. Res. Med. Sci., 1(4): 448-450.

WHO, 2014 Geneva. Dengue and severe dengue. World Health Organization. 2014. Fact sheet no. 117.

\section{How to cite this article:}

Balamurugan, R., Sunil S. Shivekar, R. Gopal, M. Kaviraj, T. Mangaiyarkarasi and Saleem, M. 2016. Seroprevalence of Dengue in Rural Tertiary Care Hospital at Puducherry-A Retrospective Study. Int.J.Curr.Microbiol.App.Sci. 5(6): 130-134. doi: http://dx.doi.org/10.20546/ijcmas.2016.506.016 